\title{
TEACHER MANAGEMENT OF INTEGRATED ISLAMIC ELEMENTARY SCHOOL IN BENGKULU PROVINCE
}

\section{Citra Dewi}

Universitas Dehasen Bengkulu

citravioleta04@unived.ac.id

\section{Article History}

accepted 09/07/2018

approved 01/08/2018

published 17/09/2018

\section{Keywords}

management, teacher competence, integrated Islamic Elementary school

\begin{abstract}
Integrated Islamic elementary school is one of alternative educational institution and main choice of the society in disruption era. Meanwhile Integrated Islamict elementary school not only teach about cognitive lessons only but also combining moral values with charge material and application in all daily activities in their school. Teacher becomes the main central in learning activities at integrated Islamic elementary school. The goals of this research to know and to analyze activities some aspects; (1) planning; (2) organizing; (3) implementation; (4) supervision, and (5) evaluation. The Method that used in this research is qualitative by using technique interviews, observations, and documentation. The results stated that (1) the planning was formed team formulation teacher recruitment, socialization, teacher test competence, and made the decision of the teacher chosen,(2) the activities that in organizing step was coordinating on the associated unit in school in guidance of new teachers, (3) Activities in implementation form training basic for teachers, internships, workshops, and training, (4) the activities of supervision conducted in the form of monitoring of learning through supervision learning in class, supervision of instructional tools, and (5) the activities in evaluation step were performance and evaluation learning that shows results corresponding with expected criteria although still found teachers who are not productive in writing creation scientific aspect.
\end{abstract}

Social, Humanities, and Education Studies (SHEs): Conference Series https://jurnal.uns.ac.id/shes

p-ISSN 2620-9284 e-ISSN 2620-9292 


\section{PENDAHULUAN}

Pendidikan merupakan suatu bidang garapan yang melibatkan dan memerlukan komitmen semua stakeholder, baik dari kalangan masyarakat bawah hingga kalangan atas. Jika semua masyarakat memiliki kesadaran akan pentingnya pendidikan sebagai pilar penentu kemajuan bangsa telah baik, maka pertanda bahwa negara itu telah berkembang, dan kemajuan dalam sektor pendidikan sangatlah penting dan secara perlahan akan meningkatkan taraf kesejahteraan hidup masyarakat sesuai dengan tujuan negara.

Arah pendidikan bangsa Indonesia sudah tertuang jelas dalam UU RI No. 20 Tahun 2003 BAB II Pasal 3 tentang fungsi dan tujuan pendidikan nasional, Pasal 3: fungsi pendidikan nasional adalah "Pendidikan nasional berfungsi mengembangkan kemampuan dan membentuk watak serta peradaban bangsa yang bermartabat dalam rangka mencerdaskan kehidupan bangsa, bertujuan untuk berkembangnya potensi peserta didik agar menjadi manusia yang beriman dan bertakwa kepada Tuhan Yang Maha Esa, berakhlak mulia, sehat, berilmu, cakap, kreatif, mandiri dan menjadi warga Negara yang demokratis serta bertanggung jawab"

Keberadaan guru menjadi sangat penting sebagai tenaga pendidik harus disadari oleh semua stakeholder, utamanya pemerintah sebagaimana dituangkan dalam UU RI Nomor 20 Tahun 2003 tentang Sistem Pendidikan Nasional Pasal 29 Ayat 2 "pendidik merupakan tenaga profesional yang bertugas merencanakan dan melaksanakan proses pembelajaran, menilai hasil pembelajaran, melakukan pembimbingan dan pelatihan, serta melakukan penelitian dan pengabdian kepada masyarakat, terutama bagi pendidik pada perguruan tinggi.

Konsep profesional yang termaktub pada UU Guru dan Dosen merupakan upaya kuat pemerintah dan seluruh rakyat Indonesia tentang pendidikan yang layak dan pantas menyandang predikat profesi guru atau dosen. Guru dan dosen merupakan bidang pekerjaan khusus yang dilaksanakan berdasarkan prinsip berikut: (a) memiliki minat, bakat, panggilan jiwa, dan idealisme, (b) memiliki komitmen untuk meningkatkan mutu pendidikan, keimanan, ketaqwaan dan akhlak mulia, (c) memiliki kualifikasi akademik dan latar belakang pendidikan sesuai dengan bidang tugas, (d) memiliki kompetensi yang diperlukan sesuai dengan bidang tugas, (e) memiliki tanggungjawab atas pelaksanaan tugas keprofesionalan.

Menurut Finch \& Crunkilton, (1992:220) menyatakan "those taks, skills, attitudes, values, and appreciation are competencies that are deemed critical to successful employment".Pernyataan ini bermakna kompetensi adalah tugas, keterampilan, sikap, nilai, apresiasi adalah yang diberikan dalam rangka keberhasilan hidup/penghasilan hidup. Hal ini dapat disimpulkan kompetensi merupakan kombinasi antara ilmu, kepandaian, dan aplikasi dalam melakukan kewajiban di mana berada.

Kompetensi dosen terkait dengan kewenangan melaksanakan tugasnya, baik berperan sebagai alat pendidikan, dan kompetensi pedagogis yang berkaitan dengan tugas guru dan Dosen pada pengawasan sikap siswa belajar (Djohar, 2006 : 130). Kemudian Suparlan (2008:93) menambahkan pengelolaan pembelajaran, pengembangan profesi, dan penguasaan akademik adalah tiga komponen standar kompetensi guru.

Menurut Ngainun Naim (2009:60) guru dan dosen yang memiliki kompetensi memiliki kemampuan yang dihandalkan apabila menguasai empat kompetensi. Keempat kompetensi tersebut adalah pengenalan peserta didik secara mendalam, penguasaan bidang studi baik disiplin ilmu (disciplinary content) maupun bahan ajar dalam kurikulum sekolah, penyelenggaraan pembelajaran meliputi perencanaan dan pelaksanaan pembelajaran, evaluasi proses dan hasil belajar, serta tindak lanjut untuk perbaikan dan pengayaan dan pengembangan kepribadian dan profesionalitas secara 
berkelanjutan merupakan kompetensi yang bersifat holistik dan integratif dalam kinerja guru dan Dosen.

SDIT IQRA 1 Kota Bengkulu merupakan institusi pendidikan di bawah naungan Kementerian Pendidikan Nasional yang meiliki jaringan di seluruh wilayah Indonesia merupakan bagian terpadu dari lembaga pendidikan bangsa ini telah berkontribusi dan ikut mencerdaskan kehidupan bangsa melalui jalur pendidikan formal. SDIT IQRA 1 Kota Bengkulu merupakan sekolah yang memilki karakter yang kuat dengan harapan: Pemerintah dan masyarakat hendaknya berusaha memberdayakan warga negara untuk menjadi manusia yang berkualitas.

Berjalan atau tidaknya manajemen SDIT IQRA 1 Kota Bengkulu merupakan penentu dari ketercapaian visi, misi, dan tujuan yang telah dibuat, bagaimana SDIT IQRA 1 Kota Bengkulu melakukan penerimaan tenaga pendidik dan tenaga kependidikan, sebagai penentu mutu lembaga yang dimulai dari perencanaan, rekrutmen, seleksi, penempatan, pelatihan dan pengembangan, serta evaluasi. Berdasarakan itulah penulis tertarik untuk meneliti SDIT IQRA 1 Kota Bengkulu sebagai lembaga pendidikan sekolah Islam terpadu (SIT) yang dalam aktivitasnya berorientasi pada nilai-nilai agama (islam) hubungannya dengan penerapan manajemen pembinaan guru di sekolah dasar berbasis Islam terpadu.

\section{METODE}

Tujuan umum penelitian ini untuk mengetahui dan mendapatkan gambaran menajemen pembinaan guru di SDIT IQRA 1 Kota Bengkulu. Penelitian ini akan meneliti bagaimana SDIT IQRA 1 merencanakan tenaga pendidik, proses rekrutmen tenaga pendidik, proses seleksi tenaga pendidik, proses penempatan tenaga pendidik dan tenaga kependidikan, proses pengembangan tenaga pendidik, serta evaluasi terhadap ketercapaian harapan kinerja tenaga pendidik.

Tempat penelitian diadakan di SDIT IQRA 1 Kota Bengkulu yang beralamat di Jalan Semeru Raya, Kelurahan Sawah Lebar, Kecamatan Ratu Agung, Kota Bengkulu. Pemilihan lokasi ini, didasarkan pada bahwa sekolah ini merupakan sekolah unggulan dan percontohan dengan sistem manajemen yang relatif baik, hal ini dibuktikan dengan jumlah siswa sekolah swasta yang banyak yakni 800 orang disertai prestasi akademik dan non akademik yang baik ditingkat lokal, nasional, hingga internasional. Selanjutnya sekolah ini memiliki lulusan dengan hasil akademik yang mampu mengalahkan sekolah negeri di Kota Bengkulu maupun di Provinsi Bengkulu.

\section{HASIL DAN PEMBAHASAN}

Dari hasil wawancara dan observasi langsung yang dilakukan oleh peneliti beberapa kegiatan yang dilakukan dalam tahapan manajemen pembinaan guru adalah sebagai berikut:

\section{Perencanaan}

Pada tahap perencanaan Sekolah Dasar Islam Terpadu lqra 1 kota Bengkulu membentuk tim pengembangan sumber daya manusia yang bertugas untuk melakukan perekrutan guru baru sesuai dengan kebutuhan sekolah. Dalam proses perekrutan guru baru dilakukan sosialisasi kepada masyarakat secara luas baik itu melalui media cetak atau pun media sosial secara online dan terbuka. Dari 
sosialisasi yang dilakukan banyaknya aplikasi lamaran yang di ajukan oleh calon guru di seleksi terlebih dahulu oleh tim pengembangan SDM secara administratif yang memenuhi syarat. Bagi calon guru yang memenuhi syarat dilakukan pemanggilan untuk mengikuti tes. Adapun jenis tes yang harus diikuti oleh calon guru menurut wawancara dengan ketua Tim pengembangn SDM Sekolah Dasar Islam Terpdu Iqra 1 Kota Bengkulu Bapak Pudi Hartono, S.Pd. mengatakan bahwa tes yang dilakukan adalah tes potensi akademik, tes mengaji, tes micro teaching, tes praktik sholat dan wawancara. Setelah serangkaian tes dilakukan hasil yang diperoleh melalui rekapitulasi dan rapat tim maka bagi calon guru yang diyatakan lulus diumumkan pada media online dan media cetak. Pelaksanaan rekrutmen guru baru ini diakhiri dengan pemanggilan guru yang lulus seleksi dengan penenempatan yang telah disepakati oleh pihak Kepala Sekolah dan persetujuan dari Yayasan.

\section{Pengorganisasian}

Pada tahapan pengorganisasian dilakukan beberapa kegiatan yaitu pihak sekolah berkoordinasi dengan pihak yayasan untuk melakukan pembinaan terhadap guru baru yang telah lulus seleksi. Pihak sekolah memberikan daftar nama guru baru dan akan diproses SK pengangkatan oleh yayasan. Selanjutnya dilakukan koordinasi untuk tahap pembinaan dari masing-masing unit.

\section{Pelaksanaan}

Berdasarkan observasi dan wawancara yang dilakukan pada tahap pelaksanaan pembinaan guru di sekolah dasar bebrbasis Islam terpadu, yaitu ;(a) dilaksanakannya masa orientasi guru selama tiga hari pertama masuk kerja. Masa orientasi dilakukan dengan pemberian materi berupa aturan kepegawaian, pelayanan, kompetensi guru, metode dan pendekatan dalam pembelajaran serta pembuatan perangkat pembelajaran, dan evaluasi., (b) menjadi guru pendamping yang diasuh oleh guru senior. Pada tahapan orientasi ini selain materi pembelajaran kebiasaan dalam beribadah juga menjadi kewajiban,misalnya tilawah, hafalan quran, sholat fardhu, sholat Dhuha dan lain sebagainya. (c) Pengembangan sumberdaya manusia lanjutan. Pada tahap ini dilakukan selama satu semester berupa studi banding, pelaksanaan lomba Al-Fida award berupa lomba karya tulisnilmiah bagi buru, tes ketuntasan tahsin, tes hafalan juz 30 , pelatihan pembelajran, pelatihan problem solver.

\section{Pengawasan}

Pada tahap pengawasan dilakukan beberapa kegiatan yaitu: (a) dibentuk tim Kelompok Kerja Guru pada kelas pararel. Tim KKG bertugas membuat perangkat pembelajaran dan melaksanakan supervisi perangkat pembelajaran dan supervisi proses pembelajaran di kelas. (b) supervisi lanjutan dilakukan oleh tim yang dibentuk oleh pihak sekolah dilakukan dalam jangka waktu 6 bulan. Adapaun tim ini membuat jadwal supervisi, melaksanakan supervisi, membuat laporan supervisi, dan melaporkan hasil supervisi kepada Kepala Sekolah. Hasil supervisi akan ditindak lanjuti oleh Kepala Sekolah.

\section{Evaluasi}

Hasil monitoring yang diberikan oleh tim supervisi sekolah dipelajari dan dibahas dalam rapat pimpinan sekolah. Dan hasilnya dilaporkan kepada yayasan. 
Hasil terbaik untuk pembinaan guru diberikan penghargaan pada setiap akhir tahun pelajaran, demikian sebaliknya bagi guru yang terdapat hasil supervisi kurang baik dilakukan pemanggilan secara intensif dan pengawasan lanjutan. Bila tidak memiliki perubahan maka guru diberikan surat peringatan.

\section{KESIMPULAN}

Dari hasil penelitian dapat disimpulkan bahwa manajemen pembinaan guru sekolah dasar berbasis Islam Terpadu dilakukan melalui tahapan perencanaan yang baik, sistem organisasi yang terstruktur, pelaksanaan pembinaan yang bertahap, bentuk pengawasan yang terjadwal dengan baik serta evaluasi pembinaan yang melibatkan berbagai pihak dalam pengambilan keputusan.

\section{DAFTAR PUSTAKA}

Dhojar, (2006). Teori-Teori Belajar. Jakarta : Erlangga

Finch C.R. Crunkilton, J.R. (1992). Curriculum Development in Vacational and Technical Education. Boston : Allyn and Bacon.

Ngainun, Naim. (2009). Menjadi Guru Inspiratif. Jogjakarta : Pustaka Belajar.

Suparlan. (2008). Wawasan Pendidikan : Sebuah Pengantar Pendidikan. Jogjakarta : Ar-Ruzz Media

Undang-Undang Nomor 14 Tahun 2005 tentang Guru dan Dosen.

Undang-undang Nomor 20 Tahun 2003 tentang Keuangan Negara. 